\title{
Performance Sport: Education in Fair Play? (Some Empirical and Theoretical Remarks*)
}

\author{
GUNTER A. PILZ \\ Universität Hannover, Institut für Sportwissenschaft, Am Moritzwinkel 6, \\ 30167 Hannover/Germany
}

\begin{abstract}
In this report the question of education in fair play in football clubs is critically discussed. The results of a representative study of the attitudes of juvenile football players, football coaches and 12-14 year-old pupils towards fair play and violence verify that violence and unfairness are the logical consequences of the comprehension of a sport that is solely or primarily oriented towards success. The longer 12-14 year old juveniles play soccer in a soccer club, the more they are willing to see intentional fouls as fair; thus the more they internalize the moral of "fair foul". On the basis of these results, the efforts to promote fair play and the chances of an education in fair play are discussed critically.
\end{abstract}

Fair play: the contribution of the sport to the education of youth, is willingly referred to in order to display the social significance of sport, to justify subsidies for athletics, or simply to praise the Olympic Ideal. "Athletics" and "fair play", as well as "sportmanslike" and "fair" often are used as synonyms. On the other hand, there are increasing complaints about the brutalization of the sport: the growing violence in, through, and around the sport. The principle of fair play (see: Lenk/Pilz 1989) seems to lead more and more to a technocratic moral of all or nothing; of success at any costs (Heinilä 1974). The 'will to win' in the sense of fair play has changed into the "vulgar doggedness of winning at any price" (Bourdieu 1986). Studies of aggressive behavior in sports (Frogner/Pilz 1982; Gabler 1987; Heinilä 1974; Smith 1979; Ulrich 1977) pointed out that among athletes, besides the offical rules, there exists a so-called "informal system of norms" which allows for rule violations in the interest of success in sports. The following statements will therefore address the question of education in fair play in football clubs, and what structural determinants promote foul play. On the basis of representative studies of the attitudes of juvenile football players, football coaches and 12-14 year-old pupils towards fair play and violence, I will show that violence and unfairness are the logical consequences of the comprehension of a sport that is solely or primarily oriented towards success. In other words; violence and foul play are the norm rather than the exception when it comes to success-oriented sports. Athletes who violate sporting rules are representing the "avant-garde of a new sporting identity-type" (Blinkert 1988). On the basis of these results, the efforts by German and International sport organisations to

\footnotetext{
* Invited paper for the interdisciplinary meeting "sport and fair play" at the Olympic Scientific Congress 1992 (14th-18th July) in Benalmadena.
} 
promote fair play and the chances of an education in fair play will be discussed critically.

\section{Comprehension of Fair Play: A Question of Age}

Within the framework of an initiative for education in fair play by the Lower Saxony Football Association, we questioned 1207 12-14 year-old football players on "select teams" concerning their attitudes towards fair play and their comprehension of fair play. Some of the most interesting results will be presented and discussed. As figures 1 and 2 (p. 406) point out, the older the selected juvenile team players are, the more they tolerate intentional rule violations. In other words: The older the juvenile football players are, the more they are willing to violate the rules in the interest of winning, the more they also tolerate and legitmate rule violations, and the more they describe rule violations with the term 'fair play'. With increasing age, juveniles learn to see sporting rules as obstacles to success, and to violate the rules according the importance of the situation and the degree of the risk of punishment (Pilz u.a. 1982, p.13). This is also proven by the different acceptance and valuations of efforts to promote fair play (see figure 3 p. 407). The older the football players are, the less they accept efforts to promote fair play, and the less they believe that efforts to promote fair play can be successful.

\section{Attitudes Towards Fair Play: A Question of Sport Experience}

The differences between the player positions, the sporting aim of the football players and their football experience (number of years the juveniles have actively played football in a football club), leads to a further interesting fact confirming the hypothesis of the football club as an agent of the socialization of unfair behavior. Neither the player position, nor the sporting aim are of importance for the young football players' comprehension of fair play, valuation of different play situations, or their definition of fair play. The amount of football experience in a club is the only significant factor for the young football players' different comprehensions of and attitudes towards fair play.

Juveniles who have played for more than four years (of greater significance are those who have played for six years or more in a football club) accept rule violations more often, and describe them significantly less often as being unfair, than juveniles who have only 1-3 years of football experience in a club (see figures 4-5 p. 407-408). The fact that the juveniles questioned all had nearly the same level of performance (they all played in the highest football league for 12-14 yearold juveniles), and that they are of the same age (12-14 years old), indicates that the increasing acceptance of rule violations are the result of socialization through performance sports (the football club). At the age of 12-14 years at the latest, juveniles in football clubs learn that it is acceptable and even important to violate the rules in the interest of success. On the other hand, there is also some reason to suppose that this has something to do with a sport-specific process of selection. In the course of their sporting career in the clubs, juveniles who aren't willing to engage in foul play tend to leave the club and get involved in other sports or move to non-performance sports because of the success-orientation of the clubs. This 
supposition seems to have been proven by the high rates of fluctuation within youth football in Germany. Many juveniles who were questioned, complained that, with the increase in orientation towards success in the clubs, the fun and the pleasure of playing football decreased more and more. Thus, it seems that football clubs have indeed turned out to be an agent for the socialization of the successoriented moral of the 'fair foul'. In other words, football clubs have become the the school of unfairness.

\section{Success and Fair Play: Statements of Juvenile Players on Fair Play}

We asked the 12-14 year-old football players how they personally define fair play. In summarizing their answers, it can be found that their definitons of fair play can be differentiated (Lenk/Pilz 1989) into three groups:

- 'informal fair play' (i.e. "fair play means to play the ball also to the worse players, to integrate the less good ones and to play football first of all just for fun")

- 'formal fair play' (i. . "to do only things allowed by the rules: to adhere strictly to the rules")

- 'fair foul' (i.e. "fair play means to play foul in a limited way; only in the interest of success, and not to hurt the opposing player seriously").

As figure 6 (p. 408) shows, only 5.3 per cent of the 12-14 year-old football players have a comprehension of fair play in the sense of 'informal fair play'; 37 per cent have a comprehension of 'formal fair play'; but 57.6 per cent of the young football players define fair play in the sense of the moral of 'fair foul'. Thereby, most of the juveniles answered in the following manner:

"Fair play means only to play unfair when it is necessary."

"Fair play means not to make an uncessary foul unless you have no other chance; then you have to play foul in a fair manner."

"Fair play means to foul the opponent in a fair manner."

"Fair play means to play fair; and if you can't avoid a foul, then you have to do a foul."

"Fair play means to play rough and with tricks, but not too often, because then it's no longer fair play."

"Fair play is not to realize. To get the ball, you have to play rough and sometimes be unfair. Those who are always fair have no chance in football."

"Fair play means not to foul a player without any reason. In an important and very hard fight you have to foul in the interest of the team, but you are not allowed to make unfair fouls."

The moral of the fair foul and the legitimization of intentional rule violations are a central theme to the interest of sporting success. It seems to be the case that fair play is embarassing in a success-oriented action. For this reason, the knowledge on the one hand of the neccessity of foul play in the interest of success and becoming conscious of it; and on the other hand, not being ready to completely give up the idea of fair play, the juvenile football players establish the 
auxillary construct of 'fair foul', thereby reducing their cognitive dissonance (Festinger 1957). As figure 7 (p. 409) points out, the longer young football players are in a football club, the more they comprehend fair play in the sense of the moral of fair foul. 61.6 per cent of those 12-14 year-old football players who have played football for more then six years in a club define fair play as 'fair foul', compared to "only" 52 per cent of those who have played 1-3 years of club football. As figure 8 (p. 409) shows, more then 92 per cent of the 15-16 year-old football players have a fair play comprehension in the sense of the 'fair foul'. Success-oriented violations and rule violations as social behavior patterns were accepted (if not developed) and reinforced by the performance-sport socialization in the football clubs.

\section{Attitudes Towards Fair Play: Comparison between Football Players and Pupils}

A comparison between the attitudes of the 12-14 year-old football players and pupils of the same age who don't play football in a club substantiates the hypothesis of the football club as a socialization or selection insitution for the moral of the fair foul. Only 24.5 per cent of the questioned pupils describe fair play in the sense of 'fair foul', as opposed to 57.6 per cent of the 12-14 year-old football players (see figure 9 p. 410). 38.9 per cent of the pupils, as opposed to only 18.9 per cent of the football players evaluate the backs' prevention of a goal by making an intentional foul just in front of the penalty area as unfair. 64,5 per cent of the football players, as opposed to only 45.3 per cent of the pupils find this tactically clever (see figure 10 p. 410). On the other hand, the simulation of a foul in the penalty area in order to receive an unjustified penalty is seen as unfair by only 22.6 per cent of the pupils, as opposed to 50 per cent of the football players. 28.5 per cent of the football players, as opposed to 65.9 per cent of the pupils describe this as unfair, but tactically clever. Cheating is more accepted by the pupils than by the football players. This may be a consequence of the every-day life at school; that is, the success orientation and the combined pressure of success at school (see figures 11-12 p. 411-412).

In this context, the comparison between male and female pupils is of further interest. The female pupils have a significantly greater comprehension of informal fair play and define fair play significantly less as 'fair foul' than do their male counterparts (see figure 13 p. 412). As figure 14 p. 413 points out, only 19.6 per cent of the female pupils, as opposed to 42.2 per cent of the male pupils are ready to prevent a goal by making an intentional foul just in front of the penalty area. 22.2 per cent of the female, as opposed to 59.8 per cent of the male pupils describe the simulation of a foul within the penalty area in order to receive an unjustified penalty as unfair. 66.7 per cent of the male, as opposed to 32.7 per cent of the female pupils find this behavior unfair but tactically clever. 40 per cent of the male, as opposed to only 20 per cent of the female pupils would also be prepared to behave in such an manner (see figures $15-16 \mathrm{p} .414$ ). Thus, we must also verify clear and distinct sex differences in the attitudes to and comprehensions of fair play and the readiness to make an intentional foul. This is certainly a result of a sex-specific socialization process (see Pilz 1982). 


\section{The Coach as the Most Important Socialization Agent for Unfair Behaviour}

Aside from the parents, coaches play a very important (if not the most important) role in the socialization towards unfair behavior of young football players. Reactions of youth football team coaches toward the promotion of fair play and the corresponding answers of the juveniles point out a nearly insoluble conflict between educational and success-oriented aims and behavior orientations. Most coaches that were involved in the Lower Saxony Football Association efforts to promote fair play reacted primarily in the following way:

"Now we must take care that the boys don't forget to play successfully because of these efforts to promote fair play."

"Shit on fair play! The boys are playing too fair! They have to become more snappish."

"I didn't say anything to my team about the efforts to promote fair play because we had good chances to become champion in our league, and I feared that if my boys knew about the fair play efforts, they would shrink from doing one or the other necessary foul."

"Fair play receives too much importance. I am payed for and committed to being successful and can therefore pay no regard to the efforts to promote fair play. When a forward is running through too quickly, I don't expect my back to cut the forward down, but a 'human foul' is often spoken of. For example: when the back is blocking a forward who does not have possession of the ball; that's always a reasonable thing, and not meant to damage his health. In this situation however, I expect a foul from my player, which is on the one hand, unsportsmanlike, and also sanctioned by the rules, but on the other hand, that's also somehow clever. If this were less often the case; football surely would lose a lot."

This same coach of the youth select teams of the Lower Saxony Football Association once complained of an extraordinary young football player who had only one great fault: he refused to play foul; to go in single combat "roughly into the man". The punishment of the coach was not to invite this player to the training sessions and games of the youth select team. Is it surprising, based on the coaches attitudes towards the efforts to promote fair play, that the juvenile football players' opinions on fair play are as follows?:

"Fair play means to play successfully, but not to hurt the opposing player too seriously."

"Surely you must always think about the other team and the referee, but sometimes there must be fouls. You can't lose any game because of being fair."

"To me, fair play means to play more considerately. Nevertheless, I would probably be unfair if it were expected of me."

"Fair play means to play fairly; not to make an intentional foul unless you could prevent a goal by a foul."

"Fair play means to obey all rules, but to infringe them if necessary. Not every player can be fair all of the time."

"To be successful you can't be fair all of the time. If everybody were fair, you wouldn't need a referee. Those who only play fair; and never unfair; will never be successful players." 
"Fair play doesn't exist anymore today. Players are playing only in the interest of success."

"I am of the opinion that you can't get possession of the football cleanly because the game is too tactical. Therefore, you will have unfair but tactically clever situations during the games."

"Personally, I describe fair play as respect for the referee, the opponent players, the team colleagues, and the coach and spectators. At important games however, fair play is pushed into the background because you also personally would like to be successful."

It can be pointed out once again that fair play seems to be embarrassing if one is interested in success. Instead of learning fair play, young people are taught the contrary. For example: an 18 year-old football player of the German national youth team admitted to being forced by the coach from time to time to do things that aren't fair.

"I would try to stop the opposing player with all allowed and unfair means. The coach expects me to hold the opponent player on the stockinet if he is too fast. This is normal nowadays; those who don't play using such means would end up always being the seconds. I mean, today you don't see the hidden fouls in a game; and there are so many hidden fouls that the thought doesn't arise about whether to play fairly or unfairly, because everybody is practising hidden fouls" (Pilz/Wewer 1988, p.76).

The normality of intentional rule violations in the interest of success doesn't permit the question of fair play or foul play to arise. It is therefore important, in the sense of education in fair play, to sensitize the juveniles to this problem. The significance of the coach for education in fair play, or the socialization towards foul play, can be seen most clearly by comparing the attitudes towards fair play of those juveniles whose coaches promote fair play, with those whose coaches don't.

In the sense of progressive learning, the teams who take part in the Fair Play Cup of Lower Saxony are evaluated by the opposing teams, coaches and spectators on how fair or unfair they behaved during the matches. Through this evaluation, the juveniles are again and again forced to come to an understanding of the idea of fair play. We expect a long-term positive effect of learning through the sensitization of these juveniles.

As figure 17 (p. 415) shows, the positive attitudes of the 12-14 year-old football players towards the efforts to promote fair play, as well as the positive evaluation of these efforts, depend on the question of how the evaluation was carried out, and if the juveniles knew previously about the criteria of the evaluation. The more the juveniles were integrated into the process of the evaluation, the better informed they were about the criteria for evaluation; thus the more they become sensitized to fair play by the coaches, and the more they personally agree to fair play initiatives themselves. The figures $18-19$ (p. 415-416) also point out that the more intensely the juveniles were integrated into the process of evaluation, the more they discussed the evaluation and evaluation criteria; the more they recognized positive changes in their own fair play behavior on the playing-field.

These results clearly show that the demands for fair play and the education towards fair play aren't very fruitful as long as the pressure for success, which is loaded on the athletes as well as on the coaches, is not decreased. As long as there 
is no change, the longer unfairness and the moral of the fair foul can be interpreted as an absolutely reasonable act. It seems to me dishonest, if not to say unfair, to sue for fair play by the athletes. The following figures (20-22 p. 416-417) gain an additional importance in this context. The coaches (more often than the 12-14 year-old football players) accept the forcing of a player by the coach to eliminate an opposing player, or protestations againt the referees decisions. More than 59.1 per cent of the coaches of juvenile football players think that it is allowed to play rough if the opposing team plays rough as well. The coaches attitudes toward fair play are (as we see here) primarily determined by success-orientation.

\section{The Conflict between Success-Orientation and Fair Play: A Luxury Article?}

The conflict between success-orientation and fair play which is pointed out by these results is confirmed again and again by the fact that the winners of the Fair Play Cup finished either in first or last place in the youth football league championship. They were either more than a match for the other teams, so that they didn't need to use unfair means, or, they were so inferior that is was necessary to look for success at all costs. Corresponding to this, the winner of the 1988 Fair Play Cup wrote to us:

"We have to confess fairly, that is was relatively easy for us to play a fair and clean football because of our sportive superiority."

Thus the winners of the Fair Play Cup had the follwing goal/point results at the end of the championships: $111: 14$ and $42: 2,139: 10$ and $36: 0$ or $16: 156$ and $0: 44$. Fair play indeed seems to be promoted to a costly good that is more rarely made valid. Fair play has (so to say) degenerated to a demonstrative luxury. Consequently, fair play is no longer a question of a mental attitude, but is becoming a question of opportunity: "In which situation am I permitted to be fair?" Obviously fair play only exists when we play just for fun or when the championship has already been decided (see Lenk/Pilz 1989). Thus, we must seriously reflect on the contribution of the sport to the education of the youths. It is therefore especially important to throw critical light on the comprehension of fair play and the success-orientiation of most of the coaches, and to set about making corrections. Club sports have indeed "substantially declined as a central socialization agency of sporting morals with regard to the dimensions of aggression and violence in sport" (Pilz u.a. 1982, p.13).

\section{Fair Play: A Problem of Definition?}

Our results further refer to the importance of clearly describing the notion of fair play. Does it mean the carrying out of the original "informal fair play"? Does it mean fair play as righteousness in the sense of Rawls (1977, Trebels 1989). Does it mean "formal fair play" that is only adherence to the rules of the sport? Does it at least include rule violations in the sense of Heringer (1990), to whom rule violations aren't unfair as long as all athletes are behaving in the same manner and the athletes (although they know this) take part in the competition? The fair play definition of Heringer (1990, p.28) is, in the context of our results, very interesting. Heringer (1990, p.28) develops his definition of fair play in four steps: 
1. "Fair is everthing that is not unfair.

2. Unfair is anything that destroys the 'wit' of the game.

3. The 'wit' of the game is the common aim of the players.

4. The common aim is to play and to win by playing."

That means; those who don't want to win are unfair. As problematical as Heringer's definition of fair play may be, our results call attention to the fact that juvenile football players develop a fair play comprehension that is oriented to the 'wit of the game', and especially to the aim of winning which means a comprehension of fair play which is more and more removed from the "informal" and "formal" fair play models, and seems to follow its own success-oriented moral. For example; all juvenile football players evaluate flaying time (the conscious slow retirement from the ball in order to delay a penalty, or by shooting the ball far out of the playing-field) as being significantly more unfair than the holding of an opposing player at stockinet, embarrassing him by forcing him to run alone in the direction of the goal or make an intentional foul play in order to prevent a goal (see figure 23 p. 418). Flaying time seems more offensive to the wit of the play and the aim of winning the game (to play and to win), then to the prevention of a goal or achieving a goal by disallowed means. It may be of interest that HERINGER's example of intentional hand playing (which he classifies as especially unfair), isn't classified as unfair by the juvenile football players. Contrary to Heringer's suppositions, in the estimation of the young football players, this type of behavior obviously does not destroy the wit of the game.

\section{The Circulation of Violence on the Playing-Field and in the Stands}

Allow me to mention a further problem with regard to the unfairness of athletics. In her study Gabler/Schulz/Weber (1982) pointed out that, after witnessing a football game, the spectators' readiness for aggressive actions increases. In hectic games with many fouls, the readiness of the spectators to engage in violence significantly increases. In other words: there is no doubt that the violence on the playing-field promotes heightened emotions and aggressiveness, and a readiness for violence in the stands. The internalized moral of the fair foul by the athletes also has an influence on the behavior and expectations of behavior of the spectators (Pilz 1982 u.a., p.13). Thus 64.2 per cent of the fans who we questioned by legitimated an intentional foul in order to prevent a goal (see figure 24 p. 418 ). Rule violations in the interest of the team are thus legitimized and expected by the fans. A dangerous cycle which is difficult to interrupt is starting here. Athletes commit fouls in the interest of success. The spectators expect the athletes to commit fouls, and by doing this, the athletes are once again reinforcing the violent attitudes and behavior expectations of the spectators which consequently leads to a dangerous heightening of emotions on the playing-field and in the stands. Thus the hostile outbursts of the fans are also related to the violence on the playing-field. The sport associations (namely the football organizations), would therefore be well-advised not only to ask for fair play from the fans, but also from the athletes, and to promote their efforts for fair play in the stands as well as on the playing-field. 


\section{Fair Play: A Problem of the Athletes, or the Conditions of Athletics? Foul Play as Risk of Modernization.}

To summarize our results, it is clear that, contrary to resounding statements and assertions, the football club is not the guardian of fair play. The performance sporting socialization of juveniles in the sports clubs is being run under the principle of fair play as a leading moral of action. Instead of fair play however, the juveniles learn with increasing age that it is more important to violate the rules in the interest of success. Consequently, the problem of increasing unfairness in today's sports can only be solved by changing the conditions under which the athletes compete (or must compete) and creating conditions that allow athletes to practise fair play. The German Commission of the Causes and Prevention of Violence has consequently demanded the following measures from the German Football Association and the football clubs, in the interest of the control and prevention of violence in the stadium:

To emphasize fair play; to sanction rule violations more strictly; to better instruct the referees; and finally to accept the fact that changes of rules in order to reduce foul play no longer must be a taboo (Schwind/Baumann u.a. 1991).

The sport associations would indeed be well-advised to sanction rule violations more strictly. This all the more, as athletes act within a simple cost-profit-calculation principle; and as long as the costs for unfair behavior are less than the profits; athletes will use unfair means to attain their goals. This also seems to be a result of the spirit of the times. I would therefore, now like to show that intentional rule violations and the moral of the fair foul are logical, normal manifestations of the commercialization and professionalization of the modern sport.

We owe thanks to Blinkert (1988, p.397) for having pointed out that, in the course of the industrial modernization, a specific type of orientation which he describes as "utilitaristic-calculative perspective" becomes more dominant. Combined with this process are increasing numbers of situations in which "an increasing number of norm adressats evaluate the costs of illegitimate behavior as low; and the profits of illegitimate behavior as relatively high". Correspondingly, rule violations aren't regarded any longer as pathological, but as an absolutey rational form of conflict resolution. The declaration of an intentional foul as an emergency brake for the prevention of a goal, proves this in an impressive manner. This even leads to the paradoxical fact that the renunciation of rule violations are denounced as pathological, naive or just plain stupid. The consequences of this considerable maintainance of self-benefit at any price (the "singular-winner orientation") (Lenk/Pilz 1989) are: Between the heightened pressure for success and the high ideals of fair play, the well-intentioned actor is perishing with these ideals. He has only the success of being regarded as a blue-eyed idealist and a blockhead; truly representing the slogan "Nice boys finish last".

Blinkert further points out that the tiny anchoring of individuals in institutions, and social bondings as a result of the process of the individualization of modern societies (Beck 1986) have as consequences that, when a decision must be made between alternatives, the external costs of self-behavior hardly play any role. The norms have more and more the meaning of alternatives, and morality seems to be 
lump of clay that the athletes can model according to their needs. Foul play is becoming expected behavior, and even an assigned necessity. As this tiny social anchoring of personal identity and the hedonistic costs-profit-calculating attitudes spread in the course of modernization, Blinkert considers delinquents to be the "avant-garde of a new type of identity." When understood in relation to the high-performance sport, or even to a certain degree, to the performance sport (and being marked out by economization, individualization, rationalization and adapted to the modernization industrial societies), rule violating athletes and doping offenders are representing the avant-garde of a new type of sporting identity. They are a mirror-image of the one-sided values, norms and behavioral patterns of the dissolute spirit of the age: orientation towards competition, risk and status; fighting discipline, coolness and a readiness for flexibility and mobility; actionism, lust for aggression, atmospheric intoxication, and an elitist attitude. Social norms and rules under this conditions only have the significance of alternatives: one can decide for or against the rules, and the question as to which result you receive depends on considerations of opportunity. Considering the relatively low probability of being sanctioned for the majority of rule violations, and the relatively low costs of violating the rules compared with their benefits, the increase of utilitaristic attitudes in top-level athletics combined with an increase in unfairness, doping offences and violence, is not surprising (see the latest doping awards in athletism and swimming as well as the efforts for fair play by the UEFA and FIFA).

\section{Initiatives for Fair Play: The Solutions of the Problem? Pleading for an Educational and Structural Offensive}

What can be done to curtail unfairness? Many judicious initiatives have already been proposed and accepted. They emphasize the importance of reproving and modifying the complacent attitude towards violence and unfairness in sport of the athletes and the spectators, as well as the broadcasters, journalists and politicians. There are also an increasing number of pleas for the teaching of fairness in order to help individuals develop (through sports) the ability and willingness to live in peaceful coexistence. One step in the right direction seems to me to be a consistent sanction of all rule violations. The lastest efforts of sports organisations however, to more severely sanction rule violations, and to solve the doping problem by tightening up doping controls and increasings sanctions of doping offenses, has also shown its limits. The expansion of the controls comes into conflict with human rights, and complete control is also not realistic because of the corresponding financial and personal expenses (see also Blinkert 1988, p.412).

Bourdieu (1986) appropriately characterizes the development of modern sports in comparison with sports of the british aristocracy (who 'invented' the ethos of fair play) at the end of the 19 th century, by writing that, in modern sports, the "vulgar doggedness of winning at any price" pushed away the will to win within the ethos of fair play. Fair play (this has been proven by our results) degenerates more and more nowadays into a category of justification, colouring the sport cosmetically (Müller 1989, p.102). Fair play has lost its social basis. If we don't realize the need to change the social and sporting structures that force unfair behavior; "fair" and indeed "fair play" are merely empty shells of words; 
categories of justifiaction and initiatives for fair play nothing more than red herrings. Blurring tactics and alibis are too red herrings, for they are reponsible for leading to a splitting of true morals into a private moral of success and a public moral of lip service (Lenk 1988, p.1). This public moral of lip service is a public moral which can be made palatable by preaching, by flaming pleas for fair play in sports, by the increase of the control of doping and so on; and the secret moral of success is a secret moral that asks for norms of perfomance by the athletes that normally couldn't be attained without using illegal measures; a secret moral of success that colors rule violations as normal, harmless, and clever; and even asking for or legitimizing rule violations. It must not be forgotton that, to a certain degree, rule violations (the attractiveness of illegitimacy in unexciting societies) also gives sport its attractiveness. When we accept or strive for the economization and commercialization of competition sports, we then must also accept that rule violations and unfairness are necessary by-products. Thus, it stands to reason that the consequently urge to commercialize the Olympic Games is counterproductive to the efforts to promote fair play. Considering the fact that the significance of fair play only consists of the reflection of the glimmer of equality and justice in sports, this can be unmasked, and the initiatives for fair play (if structural determinants of violence and unfairness are not changed), can sensitize people to the problem of fair play and perhaps prevent the increase in unfairness.

According to Csepregi's (1992) statements on education and violence in sports, aggression can be appeased, and violence in sports brought under a certain control, through education which, first and foremost, insists on respect for the human body. What he means is the respect of the athlete for his or her own body. "Athletes can perhaps be taught not to perceive themselves only from an objective distance. They should not treat their own bodies only as instruments helping them to attain a set of goals"(Csepregi 1992, p.7). "Furthermore, education should promote an entirely different understanding of sporting activities. This means that sports should not be practised exclusively on the basis of a few principles borrowed from the world of technological organization or industrial producation. Achievements should not be evaluated by the sole rule of quantifiable success. The practice of an actitivity is more than a mere process of creating impersonal, standardized powers and squeezing out the best possible performance from human bodies. We must learn to honour the interests and desires of concrete human personalities. We should perhaps begin to discard the idea of technological domination and place sport in a new perspective"(Csepregi 1992, pp.7-8).

Considering this in conjunction with our empirical data, the summary of the expertise on "violence and sport" (Pilz u.a. 1982, p.19) receives greater significance:

"School and sport clubs are surely not independent of the general success orientation of the society, but they are also not allowed to remove themselves from distinct moral claim. This claim must be formulated more clearly by illustrating the difference betweeen the official self-comprehension of these institutions and their real effects. Most of all, it must take care to reduce the pressure to succeed which had been heaped on the children and youth."

Fair play initiatives must be measured on the basis of thes claims. Only when we overcome the simple demand for fair play, and when we realize that we must 
create conditions that allow athletes to behave fairly, will the initiatives to promote fair play contribute to an education in fair play in general and to fair play in sports specifically.

The success of all efforts to promote more fair play depends upon the question of whether or not they succeed in creating the conditions themselves for fair play. Considering this, the statement of Lenk (1988, p.1), gains further significance:

"Society must temper its over-valuation of success and the singular-winner orientation in a sizeable and controllable manner. It must moderate the absolute moral of success in order to once more give fair play a chance." "We want fair play", the swiss initiative for fair play is propagating. I ask: Who doesn't want this? Do all really want this? Who is creating the conditions for fair play? "Fair preceeds all", posits the German Fair Play Initiative. Does it preceed success as well? Who is moderating the inexorable pressure to succeed?

As long as we don't get satisfying answers to these questions, our efforts to promote fair play can hardly be successful. I believe, with Csepregi (1992, p.8) that verbal denunciation is an insufficient means of bringing violence and unfairness under control. "Only the genuine willingness to re-evaluate the present situation of sport and to change course in a radical and concrete manner, can prevent violence and unfairness." As long as we don't have this genuine willingness, and we don't take on this re-evaluation, we must also summon up tolerance for the athletes' unfairness and foul play. With this perhaps unsatisfying declaration, I will close my paper.

\section{References}

BECK, U., 1986: Risikogesellschaft. Frankfurt.

BLINKERT, B.: Kriminalität als Modernisierungsrisiko. In: Soziale Welt 1988, 397-412.

BOURDIEU, P.: Historische und soziale Vorussetzungen des modernen Sports. In: G. Hortleder, G.Gebauer, (Eds.): Sport-Ethos-Tod. Frankfurt 1986, 91-112.

CSEPREGI, G.: Education and Violence in Sports. Paper presented at the 2nd World Congress on Violence and Human Coexistence.

Montreal 11-17th July 1992.

FROGNER, E./PILZ, G.A., 1982: Untersuchung zur Einstellung von jugendli- lichen Fußballspielern und -spielerinnen zu Regeln und Normen im Sport. In: G.A. Pilz, u.a. (Eds.): Sport und Gewalt im Sport. Schorndorf, 191-244

FESTINGER, L., 1957: Theory of cognitive dissonance. Evanston.

GABLER, H., 1987: Aggressive Handlungen im Sport. Schorndorf.

GABLER, H./SCHULZ, H.-J./WEBER, R., 1982: Zuschaueraggressionen -eine Feldstudie. In: G.A. Pilz, u.a. (Eds.): Sport und Gewalt im Sport. Schorndorf, 23-40.

HEINILÄ, K., 1974: Ethics of sport. Research Report University of Jyväskylä.

HERINGER, J., 1990: Regeln und Fairneß. Woher bezieht der Sport seine Moral. In: O. Grupe, (Ed.): Kulturgut oder Körperkult. Sport und Sportwissenschaft im Wandel. Tübingen, 157-171.

LENK, H., 1988: Fair geht vor oder die Spaltung der Moral. In: dsb-Information 1988, 38, 1.

LENK, H./PILZ, G.A., 1989: Das Prinzip Fairneß. Osnabrück.

MÜLLER, U., 1989: Notizen zur Bedeutungsgeschichte der Fairneß. In: Sportunterricht 1989, 38, 2.

PILZ, G.A., 1982: Wandlungen der Gewalt im Sport. Ahrensburg. 
PILZ, G.A., 1991: Dopingsünder - Avantgarde eines neuen Identitätstyps? In: Olympische Jugend 1991, 12, 12-14.

PILZ, G.A., 1991: Leistungssport-Sozialisation: Erziehung zur Unfairneß. In: S. Redl,/R. Sobotka,/A. Russ (Eds.): Sport an der Wende. Wien.

PILZ, G.A. u.a. (Eds.), 1982: Sport und Gewalt im Sport. Schorndorf.

PILZ, G.A./WEWER, W., 1988: Erfolg oder Fair play? München.

RAWLS, J., 1977: Gerechtigkeit als Fairneß. Freiburg/München.

SCHWIND, H.-D./BAUMANN, J. u.a.(Hrsg.), 1990: Ursachen, Prävention und Kontrolle von Gewalt. Berlin, Bde I-IV.

SMITH, M.D., 1979 : Social Determinants of Violence in Hockey.: A Review. In: Canadian Journal for Applied Sport Sciences, 4, 76-82.

TREBELS, A.H., 1989: Fairneß im Sport und ihr moralischer Gehalt. Zur Diskussion der Fair play Initiativen. In: Sportunterricht 1989, 3, 85-93.

ULRICH, H.-E., 1977: Leistungssport - zwischen Idealisierung und Professionalisierung. Köln.

\section{Sport de Prestation: Une Education au Fair-Play? Quelques Observations Empiriques et Theoriques}

\section{Résumé}

La présente étude examine de manière critique le problème de l'éducation au fair-play dans les clubs de football. Les résultats d'une étude représentative des attitudes des joueurs adolescents de football, des entraîneurs et des élèves de 12-14 ans face au fair-play et à la violence confirment que la violence et la tricherie sont les conséquences logiques de la présentation d'un sport vu uniquement ou fondamentalement comme orienté vers la victoire. Pus le temps pendant lequel les jeunes jouent au football au sein d'un club se prolonge, plus ils sont enclins à considérer les coups interdits intentionnels comme loyaux, et plus ils intériorisent donc la morale d'un "coup irrégulier loyal". Sur la base de ces résultats, les efforts faits pour promouvoir le fair-play et les possibilités d'une éducation au fair-play font l'objet d'une analyse critique.

\section{Leistungssport: Erziehung zum Fair Play? \\ (Einige Empirische und Theoretische Anmerkungen)}

\section{Zusammenfassung}

Der Beitrag geht der Frage nach, wie es um die Fairneß und Fairneßerziehung im Leistungssport bestellt ist. Auf der Basis einer repräsentativen Studie über die Einstellungen jugendlicher Fußballspieler, Fußballtrainer und 12-14 jährigen Schülern zu Fair play und Gewalt im Fußballsport wird gezeigt, daß Gewalt und Unfairneß logische Konsequenzen eines Sports sind, der nur noch oder hauptsächlich am Erfolg orientiert ist. Je länger die 12-14 jährigen im Verein aktiv Fußball spielen, desto mehr sind sie bereit, absichtliches Foulspiel als fair zu bezeichnen, desto mehr haben sie die Moral der „fairen Fouls" verinnerlicht. Auf der Basis dieser Ergebnisse werden die Bemühungen der Fair play Initiativen kritisch reflektiert und mögliche Konsequenzen diskutiert.

\section{Deporte de Alto Nivel: Educacion en el "Fairplay"? Algunas Consideraciones Empiricas y Teoricas:}

\section{Resumen}

Se discute críticamente la educación del "fair- play" en los clubs de fútbol. Los resultados de un estudio representativo sobre las actitudes de jóvenes jugadores de fútbol (entre 12 y 
14 anos) y entrenadores en relación al "fair- play" y la violencia muestran que ésta y la ausencia de juego limpio son consecuencia de que el futbol está orientado exclusivamente hacia la victoria. Cuanto más tiempo estos jóvenes juegan en un club de fútbol, mayores son las infracciones del "fair-play" que realizan; es decir, interiorizan la moral de la "fair foul" (falta refinada). En base a estos resultados se discuten críticamente los esfuerzos por promocionar el "fair play" y las posibilidades de obtener resultados educativos.

lІерформативный спорт: учение фер ппей Несколько эмпирических и теоретических замечанкй

В 'той статье вопрос учения фер плей у футболы команд критичеси обсужден. Результаты иредсл авляюлеео изучения отношений юных фулболистов, тренеров и школьников 12-14 лет в сторону фер плей и насилие проверяет, ч го насилие и безчссность: щог ическис последствия нсестороности сиорта который орисптирован только в сторону успеха. Чем дальше 12-14 летние юные играют в фуібол в одном клубе

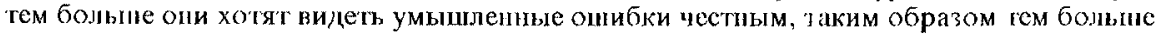
они усвоят мораль их честной опибки на основапий 'गих рсзультатов, усилие иาобы содействоват, фер плей и возможность учения на фер плей обсуждены критически.

業績スポーツ：フェアプレーにおける教育！いくつかの経験的、理論的見解

本論文では、フットボールクラブにおけるフェアプレー教有の問題が批判的に検㐿され る。青少年フットボール選手、フットボールコーチ、12 14才の生徒のフェアプレーや暴 力に対する態度の代表的な研究の結果は、アンフェアネスや暴小は何上りも成功に志向す るスポーツの包括的な論理的絬果であることを証明している。12 14才の青少年はサッカ 一クラプで誩くプレ一すればする程、故意に犯す反則をフェアよしてますます見るように なる：つまり、ますます“フェアファウル”の道德を内面化する。こうした結果に基づい て、フェアプレ一促進の努すとフェアプレーにおける改育の機会が批判的に倹得される。

\section{조직적 스포츠 : 페어플레이 정신온 학읍되는가 ?}

\section{경험적 · 이본적 논평}

이 논문은 축구텀의 페어풀레이 정신 교육에 관한 내용올 비평적으로 논의하고 있다. 청소년 축구선수, 축구 코치, 그리고 12-14세 연령 학생들의 페어플레이와 폭력에 관한 태도 연구의 대표적 결과는 스포츠 폭력과 불공정싱이 주로 성공 지향 적인 스포츠에서 발생한다는 논리적 타당성을 입증하고 있다. 12-14세 연령 칭소년 축구선수들은 선수경력이 많올 수록 그들은 공정으로서의 고의적 파울올 서슴없이 저지르는 상황을 더욱 쉽게 목격하게 된다. 따라서 이들 선수들은 “공정한 파울" 의 도덕올 더욱 내면화시키게 된다. 이들 결과를 토대로 하여 볼 때, 페어플레이 성신 조장의 노력 및 교육의 기회가 비평적으로 논의되고 있다. 
表演体育：公平竞争之教育? 某些经验主义的和理论上的评论

掠要

在本报告中，有关在足球俱乐部里的公平竞争教育问题受到了批判式的 议论。少年足球运动员、足球数练和12-14岁小学生对公平竟争和媓力的态 度的典型研究之结果证明，暴力和非公平行为是将运动理解为是追求任利的 唯一或主要目的的产物。长时间在足球俱乐部中蹋球的12-14岁的少年中， 他们的多数将故意犯规规为是公平的, 以至他们的多数将 “公平犯规” 的道 德内化。基于这种情形，对公平竞争和在公平竞争中进行教育可能性的努力， 遭受到批判式的评论。 
$\mathbf{x}$

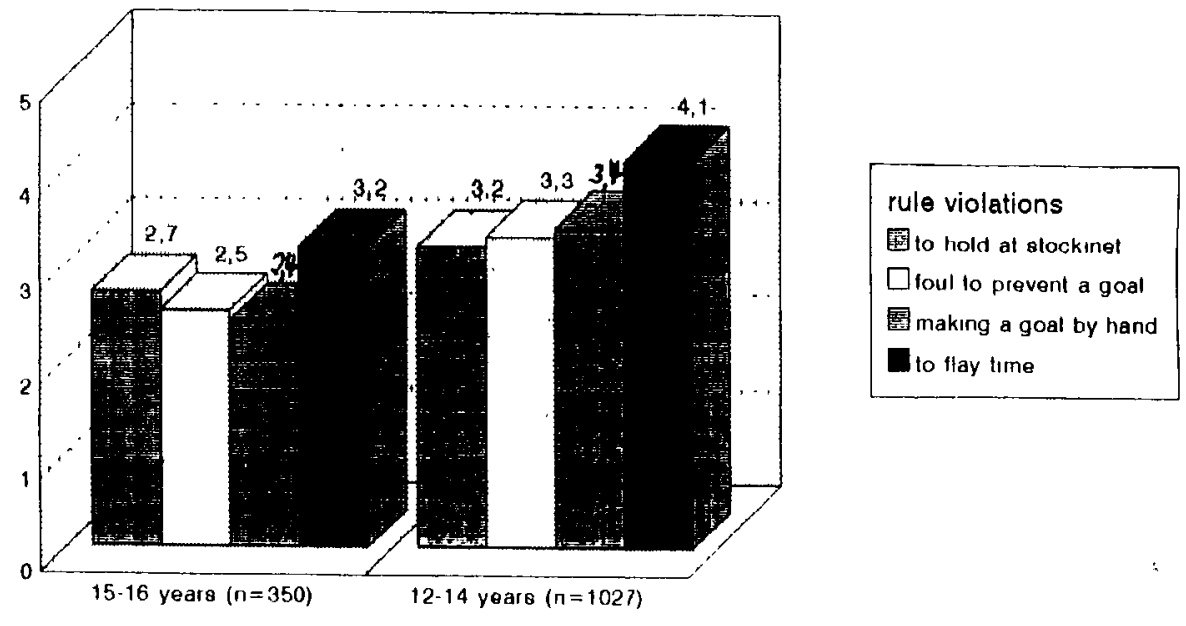

( 1 = fair, $3=$ neither nor, $5=$ unfair $)$

Figure 1: Attitudes towards different forms of rule violations

Comparison between $12-14$ and $15-16$ years old football players

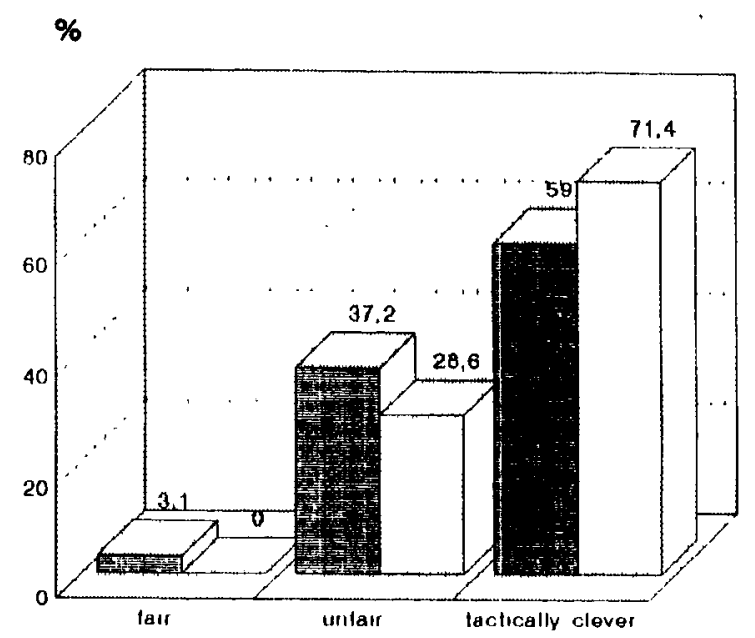

age of the lootbalt player

$12-14$ years $(n=1027)$

$\square 1516$ years $(n=350)$

The back is preventing a goal by doing an intentional foul just before the penalty area This behavior is:

Figure 2: Attitudes towards intentional foul play Comparison between 12-14 and 15-16 years old football players 

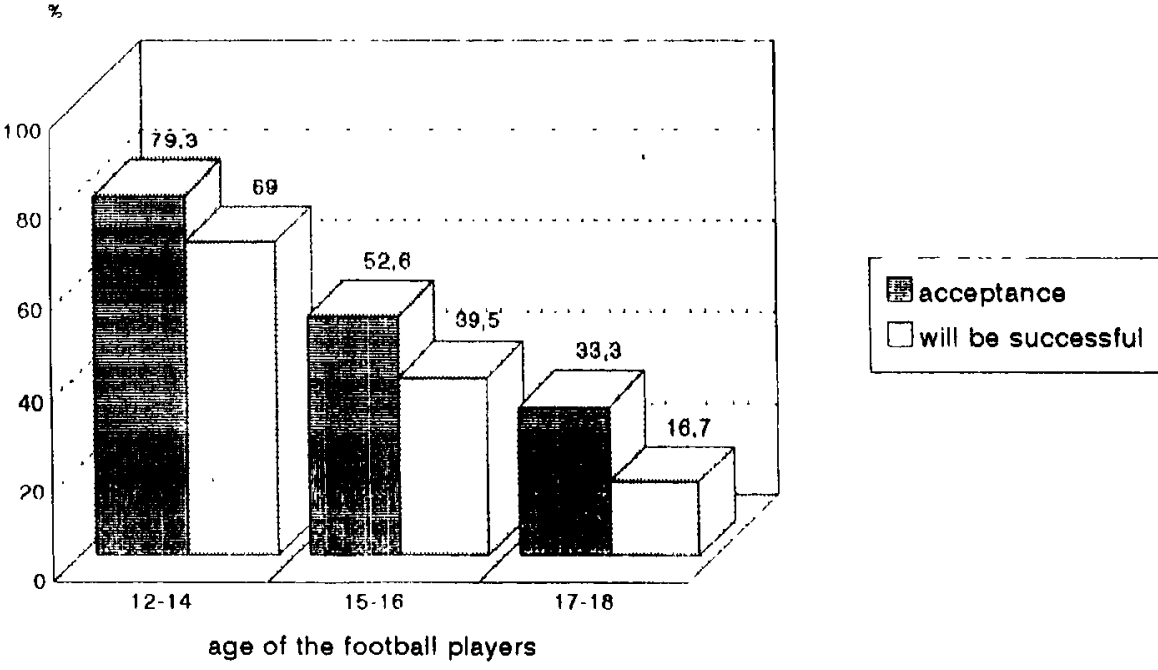

Figure 3: Acceptance and Valuation of efforts for fair play

Comparison between 12-14 ( $n=25)$; 15-16 $(n=33)$ and 17-18 $(n=24)$ years old football players of the youth all star teams of Lower Saxony

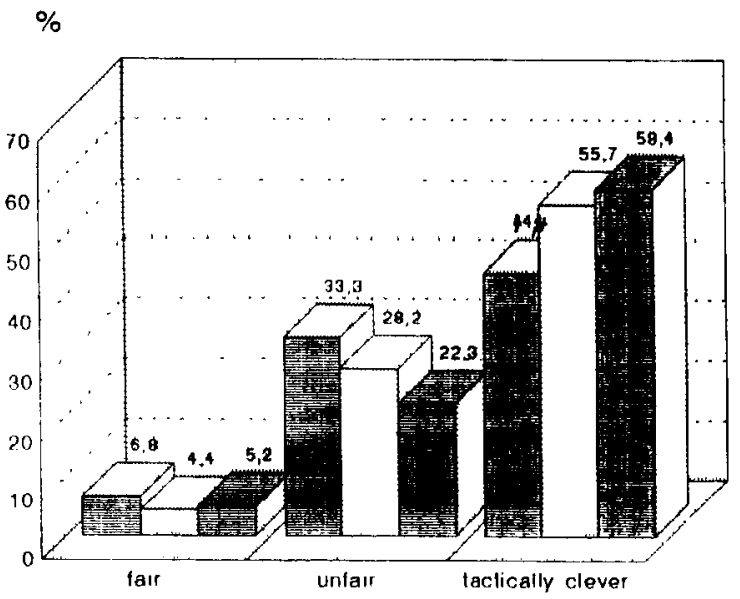

yoals of footh nliflub memberehlp

A 1 yaars $(n-122)$

$\square 4-6$ years ( $n=445$ )

遂over 6 yars $(n=460)$

The back is preventing a goal by doing an intentional foul just before the penalty area This behavior is:

Figure 4: Attitudes towards intentional foul play Comparison between 12-14 years old football players with 1-3, 4-6 or over 6 year football club membership 


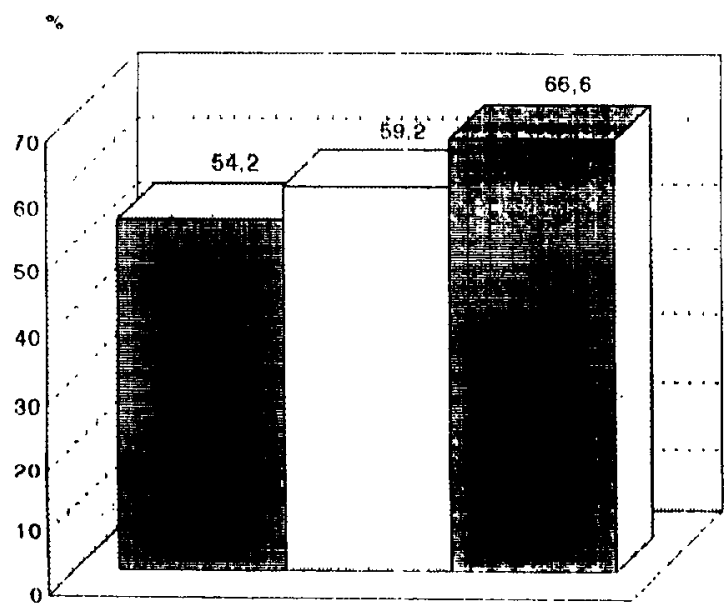

years of tontballe hib mentherstip

圈 1-3 years $(n=122)$

$\square$ 4-6 years $(n=445)$

圈 over 6 years $(n=460)$

The back is preventing a goal by doing an intentional foul just before the penalty area would do the same:

Figure 5: Readiness for intentional foul play

Comparison between 12-14 years old football players with 1-3, 4-6 or over 6 years football club membership

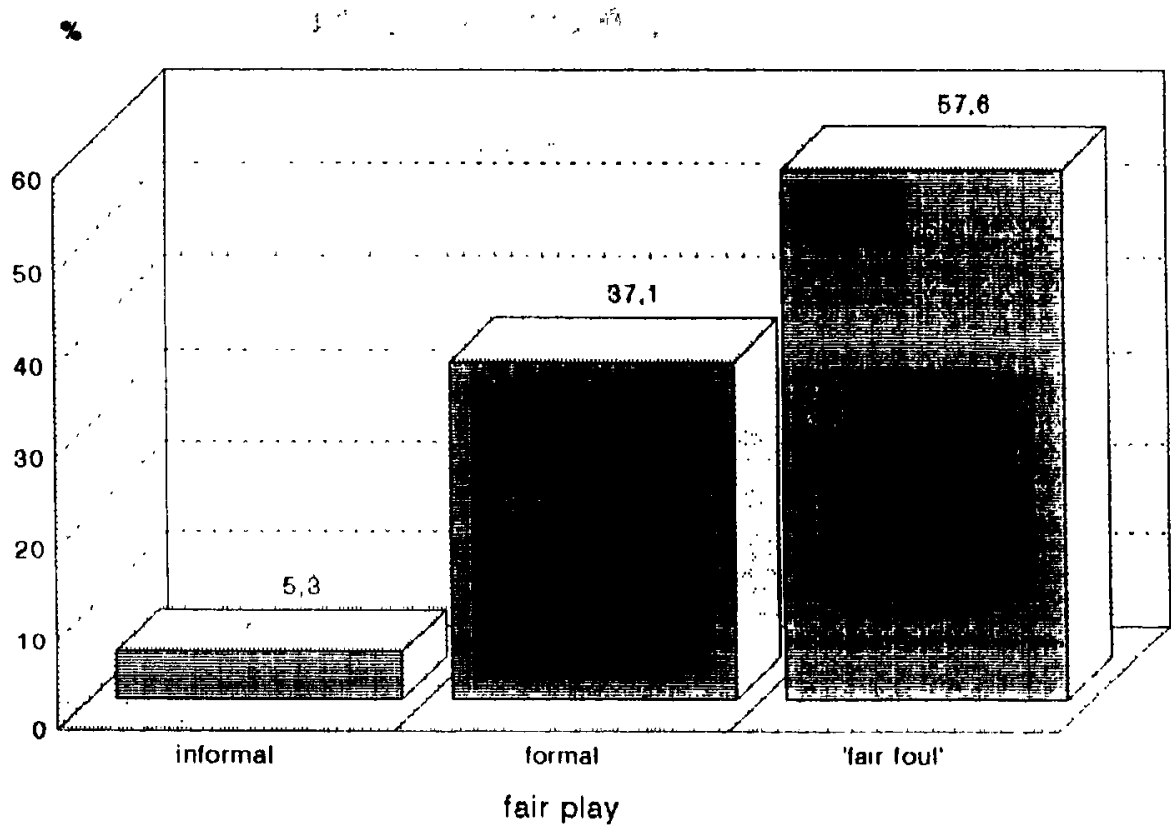

Figure 6: Personal definiton of fair play of 12-14 years old football players $(n=1027)$ 


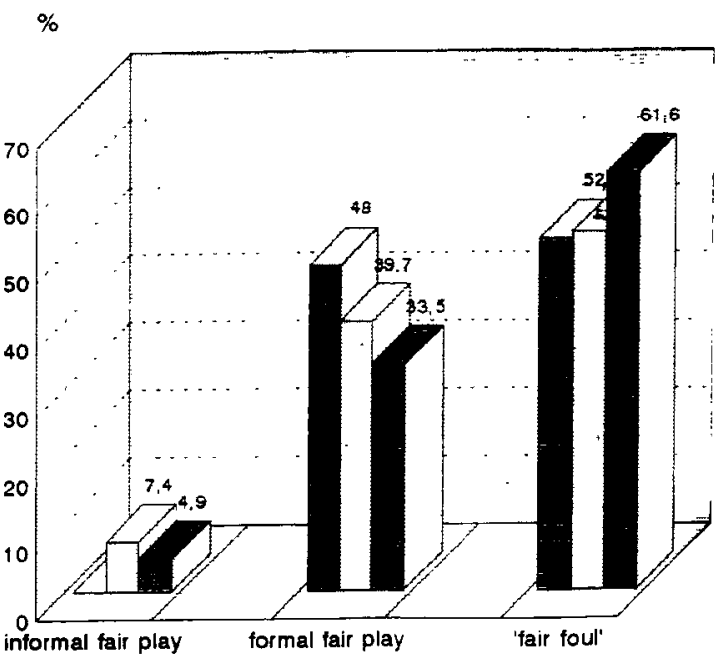

years of footballetub membership

$\because 1-3$ years $(n=122)$

$\square 4-6$ years $(n=445)$

over 6 years $(n=460)$

Figure 7: Personal Definition of fair play

Comparison between 12-14 years old football players with 1-3, 4-6 or over 6 years of football club membership

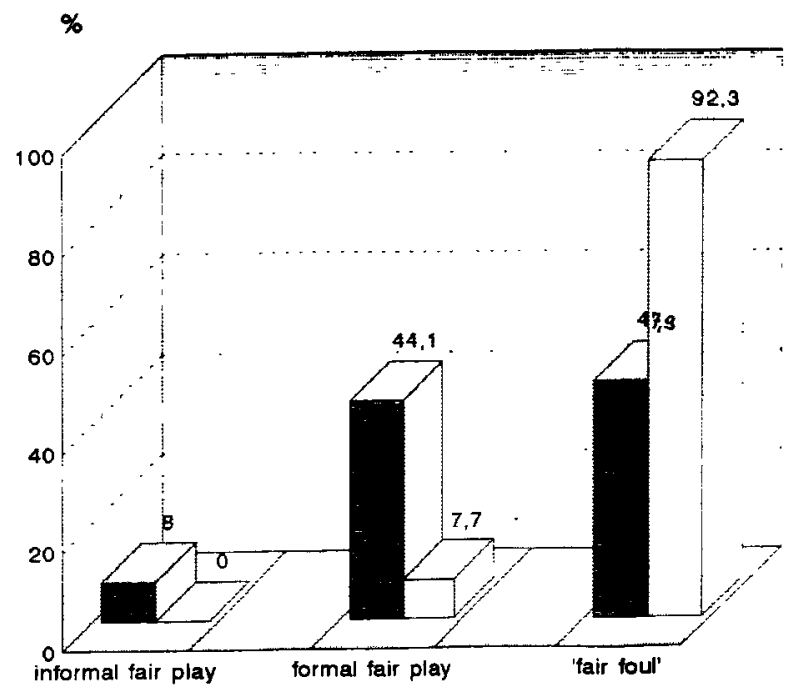

Figure 8: Personal Definition of fair play

Comparison between 12-14 and 15-16 years old football players 


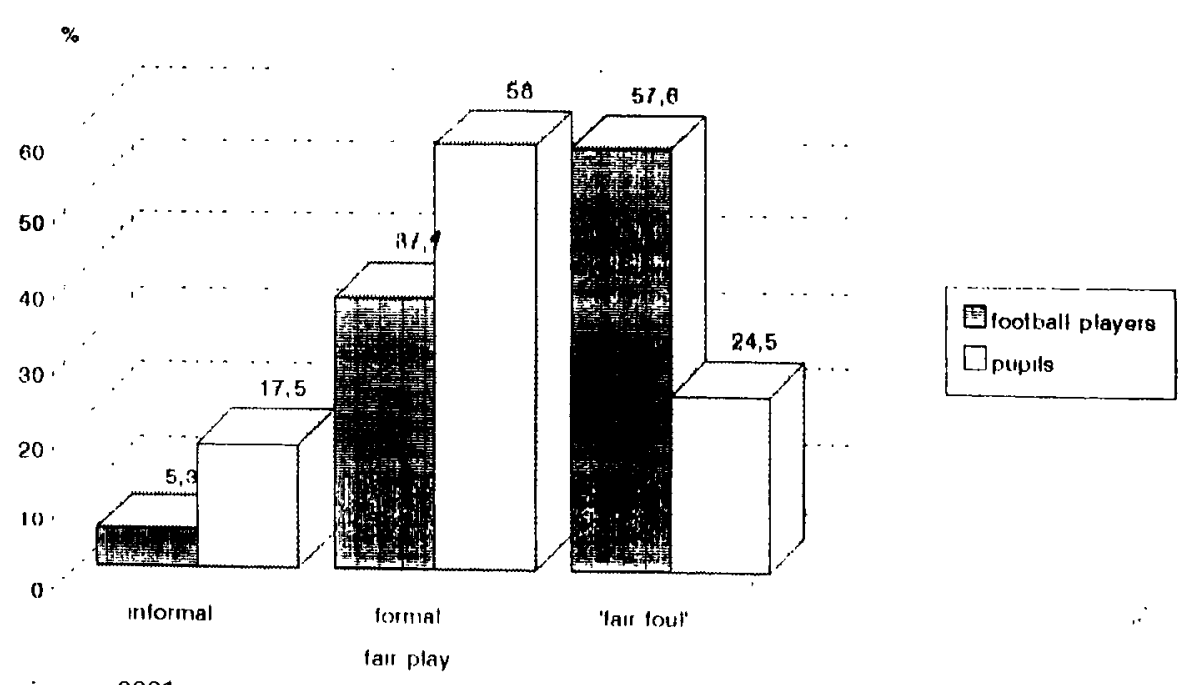

sign. > .0001

Figure 9: Personal definition of fair play

Comparison between 12-14 years old football players (n-1027) and 1214 years old pupils $(n=203)$ who don't play football in a football club.

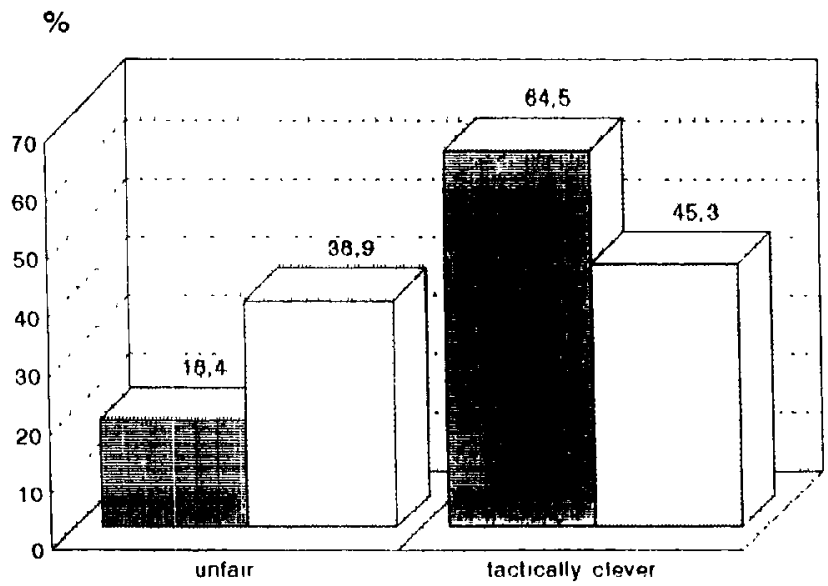

Tfootball player $\square$ pupils

The back is preventing a goal by doing an intentional foul just before the penalty area This behavior is: sign. $>.0001$

Figure 10: Attitudes towards intentional foul play

Comparison between 12-14 years old football players $(n=1027)$ and 12-14 years old pupils $(n=203)$ who don't play football in a football club. 


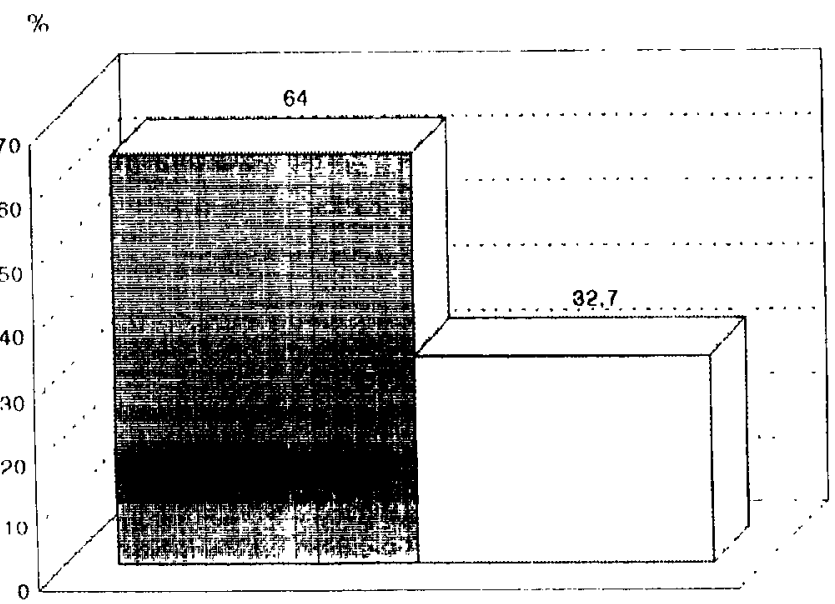

Proothall players

The forward simulates a foul in the penalty area and gets a penalty I would do the same

sign. $>.0001$

Figure 11: Readiness for an intentional foul play

Comparison between 12-14 years old football players $(n=1027)$ and 12-14 years old pupils $(n=203)$ who don't play football in a football club
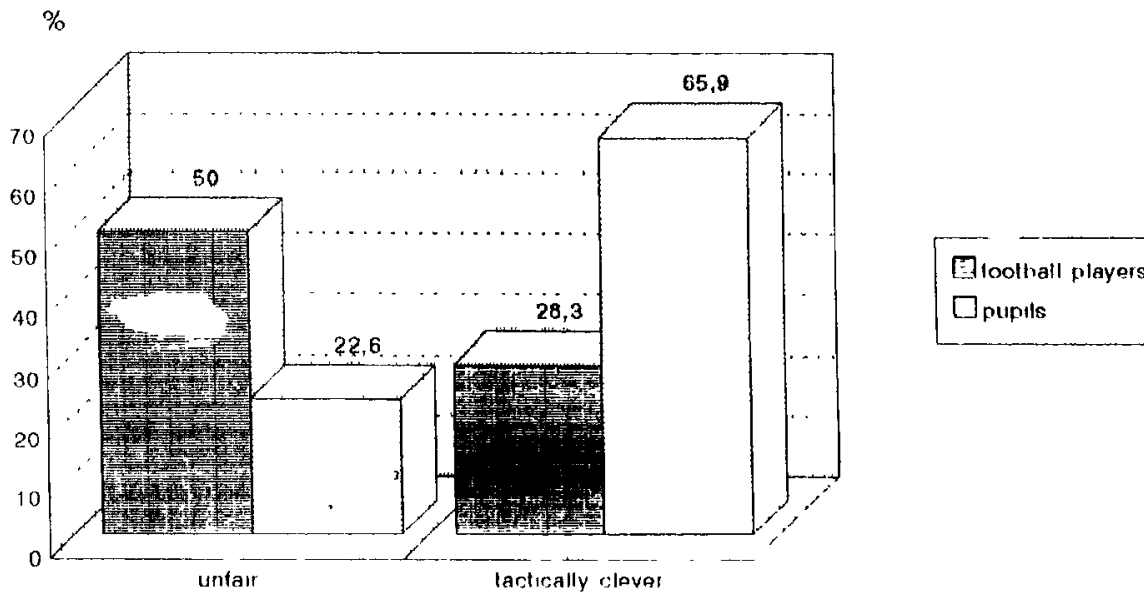

The forward simulates a foul in the penalty area and gets a penalty This behavior is:

sign. $>001$

Figure 12: Attitudes towards intentional foul play

Comparison between 12-14 years old football players $(n=1027)$ and 12-14 years old pupils $(\mathrm{n}=203)$ who don't play football in a football club 
$\%$

50

40

30

20

10
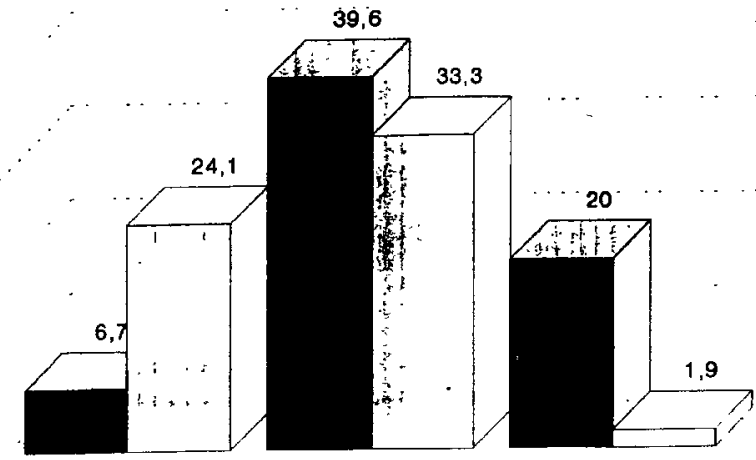

male pupils

Jemale pupils

0

informal

formal

'fair foul'

sign. $>.005$

fair play

Figure 13: Personal definition of fair play

Comparison between 12-14 years old male $(n=109)$ and female $(\mathrm{n}=119)$ pupils 


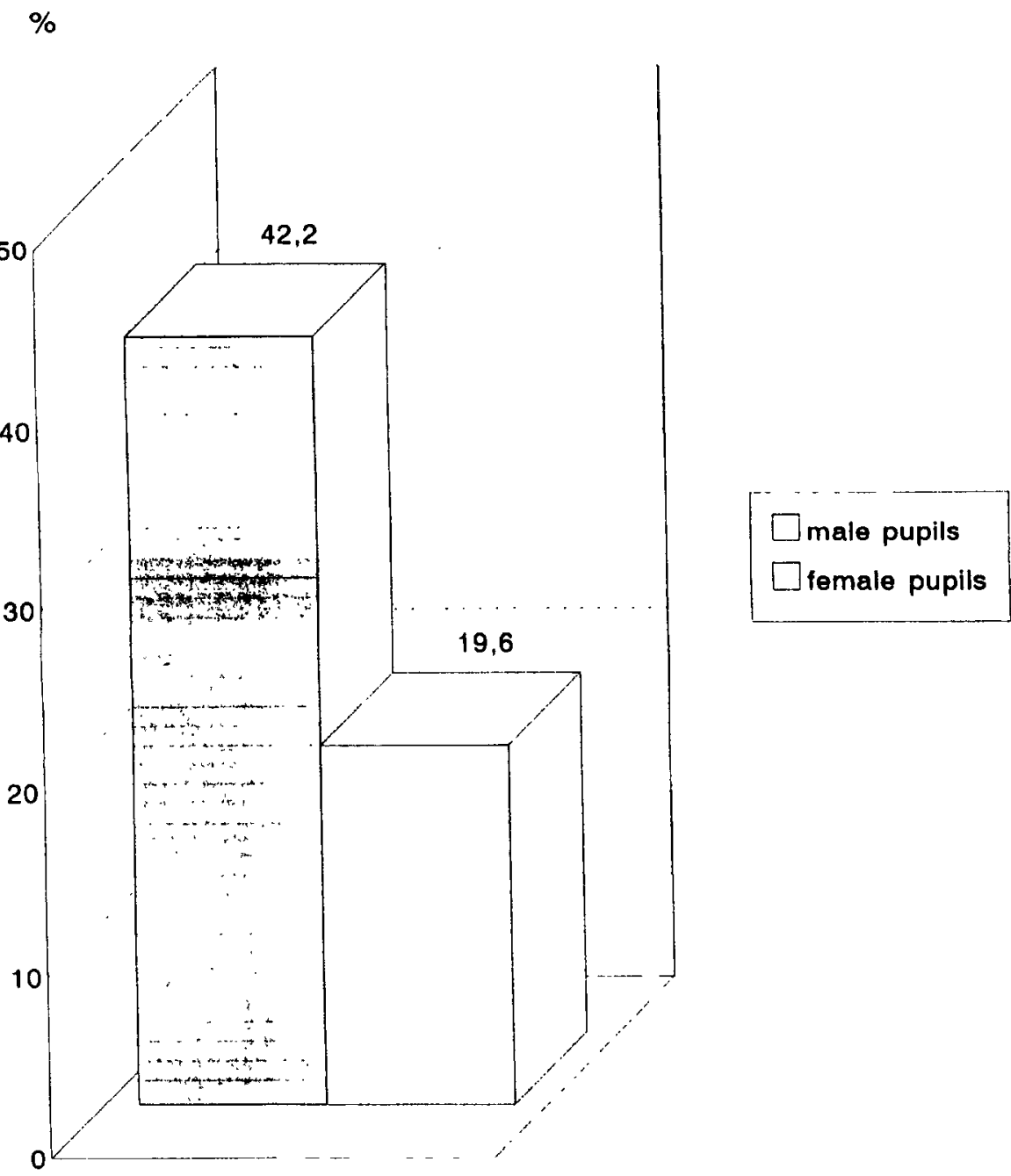

The back is preventing a goal by doing an intentional foul just before the penalty area I would do the same

sign. $>.02$

Figure 14: Readiness for intentional foul play

Comparison between 12-14 years old male $(n=109)$ and female $(\mathrm{n}=119)$ pupils 


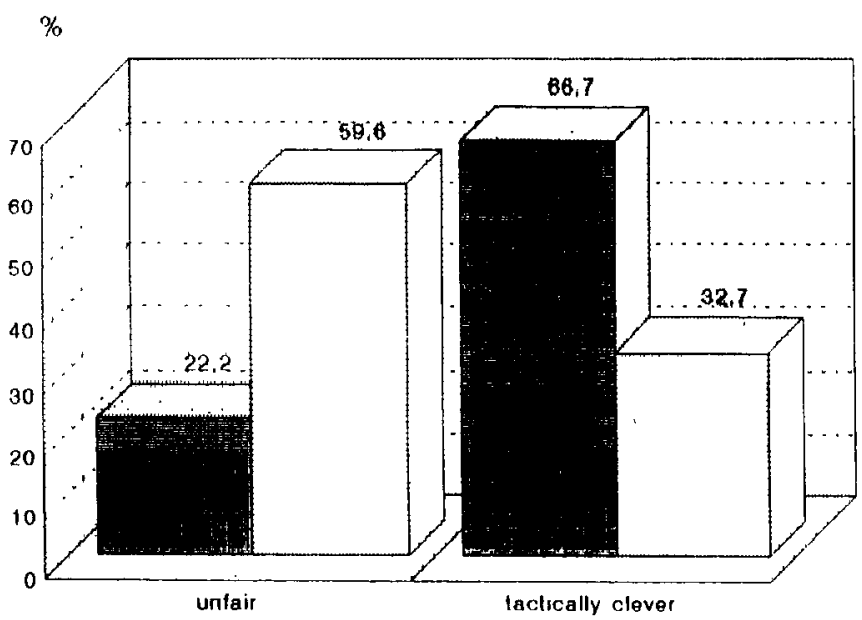

male pupils

Demale pupilo

The forward simulates a foul in the penalty area and gets a penalty This behavior is:

sign. $>.001$

Figure 15: Attitudes fowards intentional foul play

Comparison between 12-14 years old male $(n=109)$ and female $(\mathrm{n}=119)$ pupils

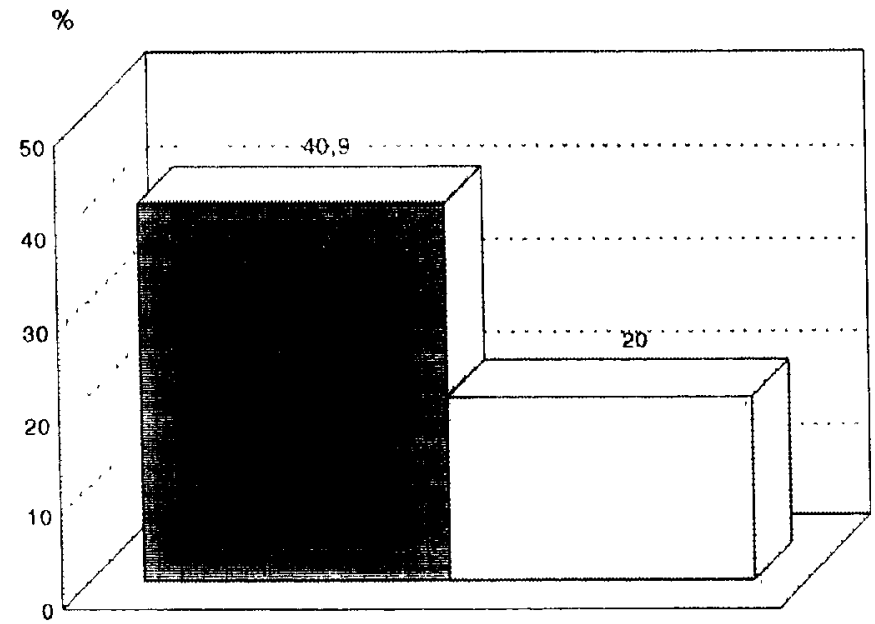

Finale pupils

Diemale pupile

The forward simulates a foul in the penalty area and gets a penalty I would do the same:

sign. $>.04$

Figure 16: Readiness for intentional foul play

Comparison between 12-14 years old male $(n=109)$ and female $(\mathrm{n}=119)$ pupils 
$\%$

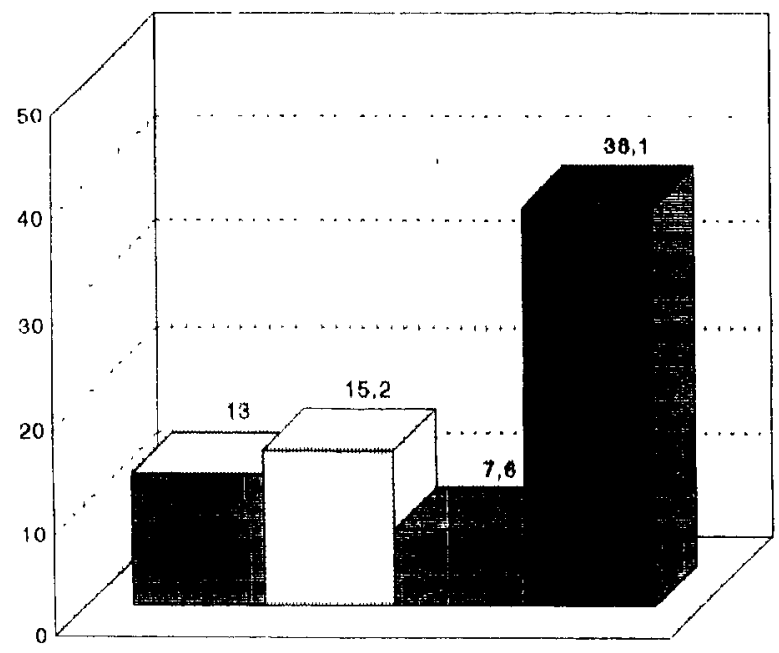

kind of valuation

图 only voted

$\square$ voled on coach's prop.

通 coach valualed alone

Wlogether after discus.

Agreement to fair play efforts

Figure 17: Kind of fair play valuation compard with the attitudes to the efforts for fair play

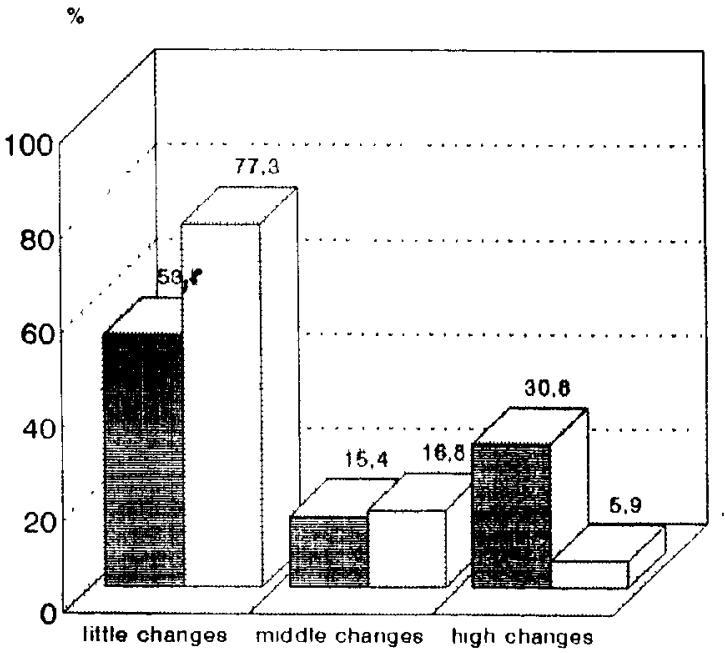

mediation

aiways discussed about

[I'm unaware of them

degree of positive changes of the own fair play behavior

Figure 18: Influence of the mediation of the criteria for valuation the fair play behavior on the changes of the own fair play behavior on the playing field 


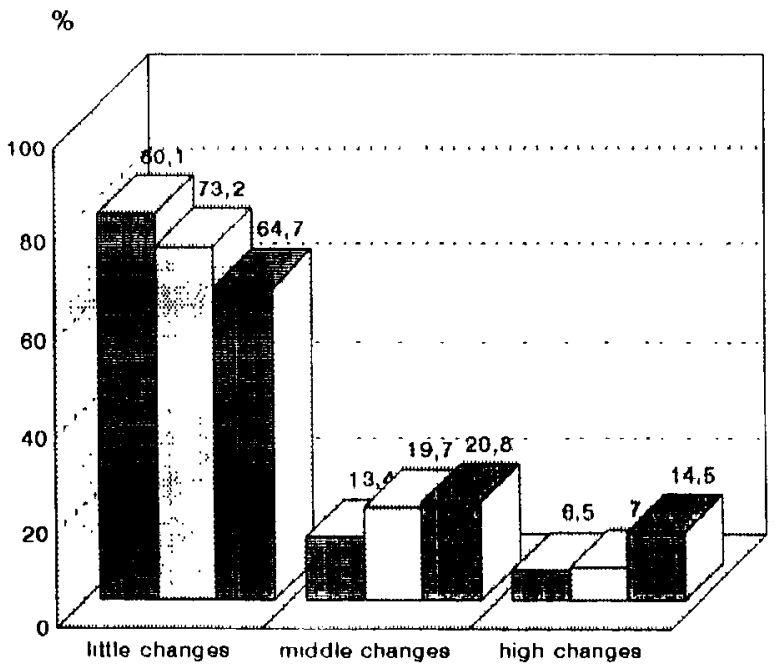

\section{kind of valuation}

圈 coach valualed alone

$\square$ voled on coach's prop.

孯 logether after diecus.

Degree of positive changes of the own fair play behavior

Figure 19: Influence of the kind of fair play valuation on the changes of the own fair play behavior on the playing field

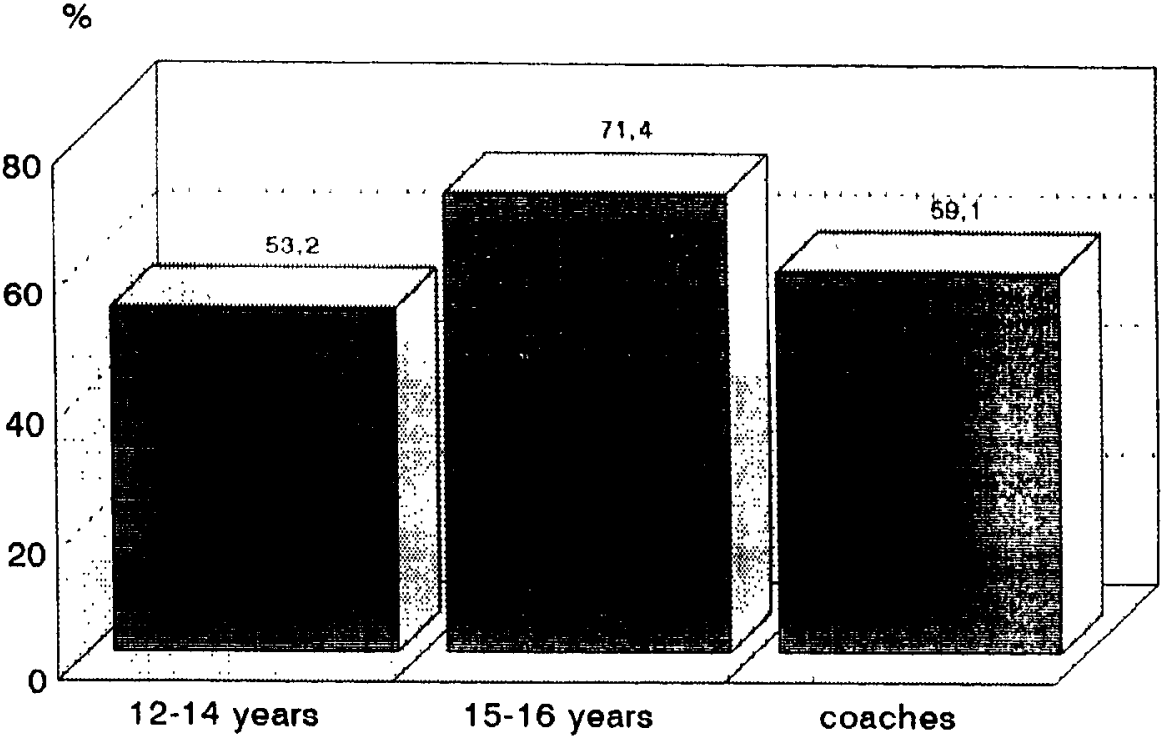

Figure 20: It is allowed to play rough, when the opponent player plays rough too Comparison between 12-14 $(n=1027)$ and 15-16 $(n=350)$ years old football players and football coaches (per cent of agreement) 


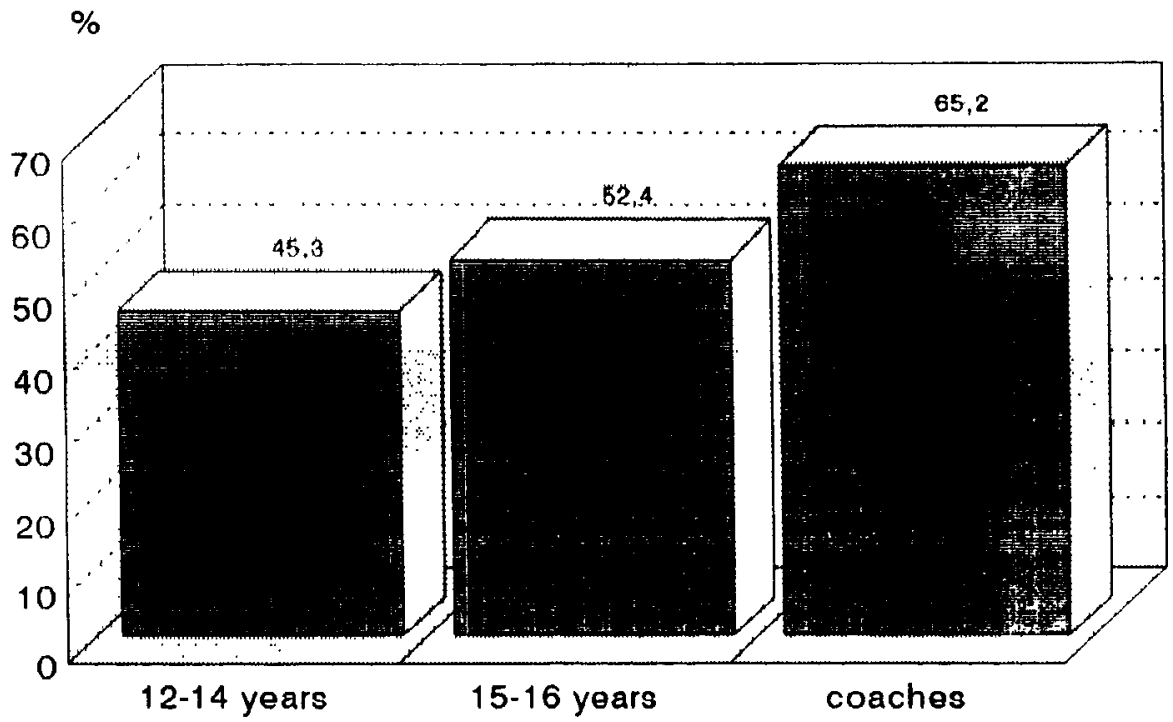

Figure 21: The coach forces a player to eliminate the opponent player Comparison between 12-14 ( $n=1027)$ and 15-16 $(n=350)$ years old football players and football coaches $(n=53)$ (per cent of agreement)

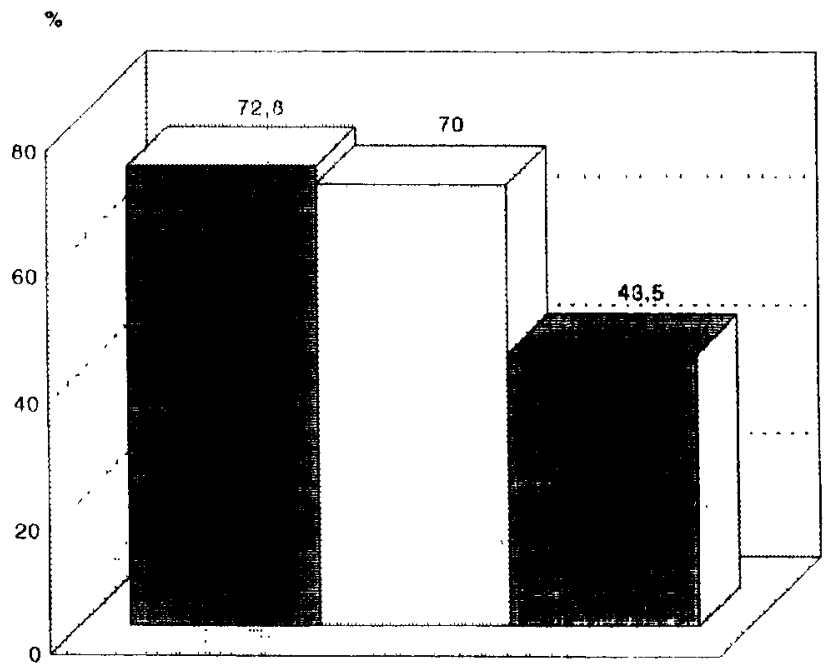

圈 12-14 years

$\square$ 15-16 years

国 coaches

Figure 22: The player has always to accept the referees' decisions without any protest

Comparison between 12-14 ( $\mathrm{n}=1027)$ and 15-16 years old football players $(n=350)$ and football coaches $(n=53)$ (per cent of agreement) 


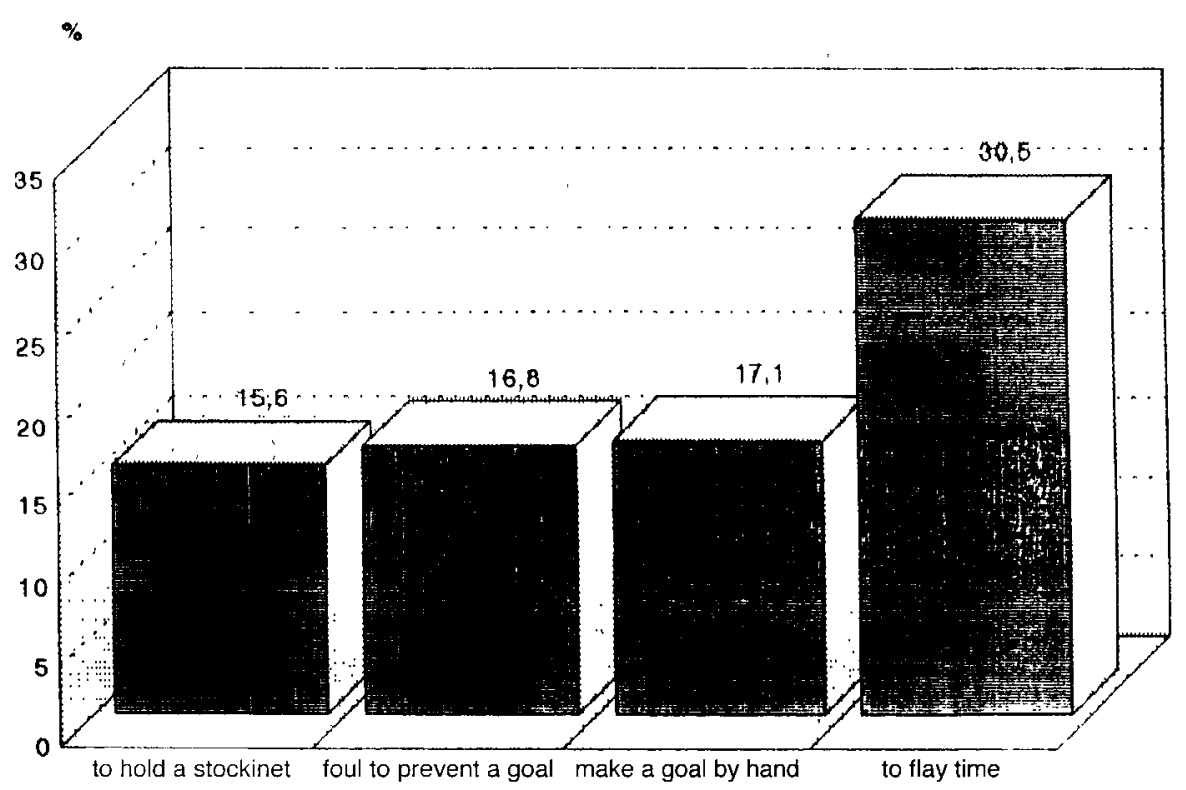

Figure 23: Attitudes of 12-14 years old football players $(n=1027)$ towards different forms of rule

(Estimation of the rule violations as unfair)

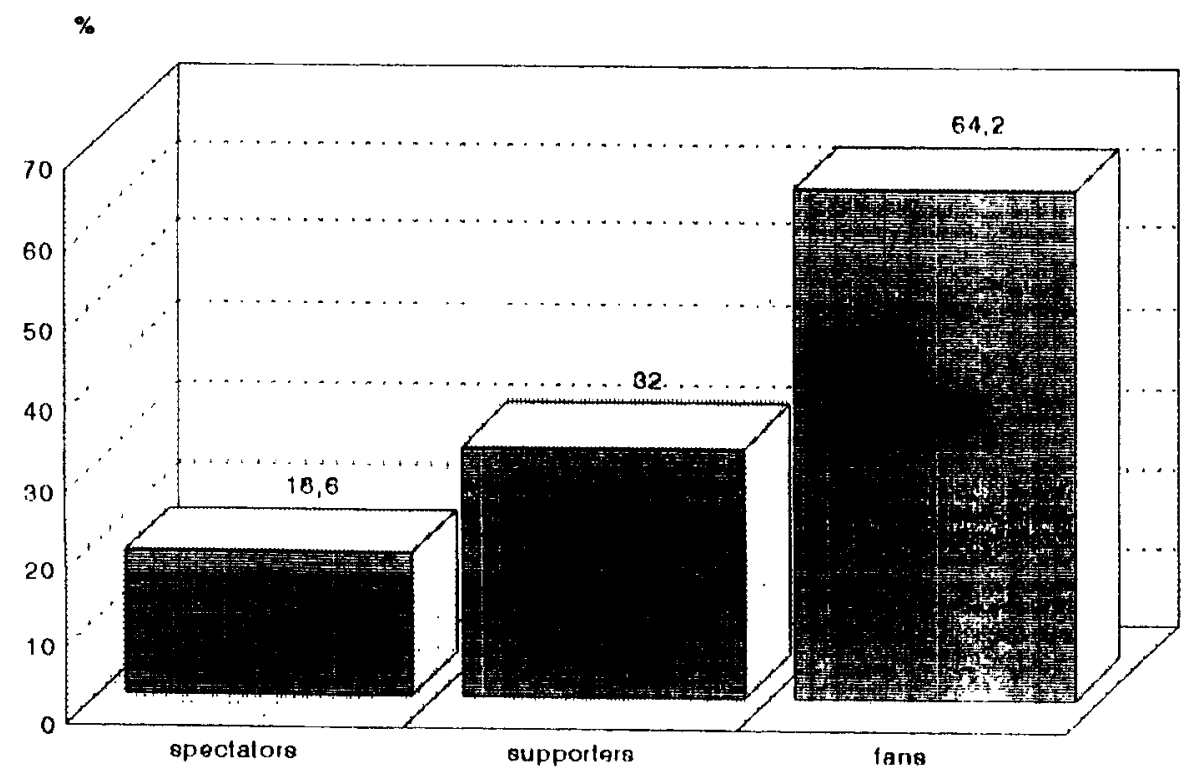

Figure 24: Legitimation of an intentional foul play

(Comparison between spectators $(\mathrm{n}=167)$ supporters $(\mathrm{n}=199)$ and fans $(n=227)$ 